\title{
ANALISIS SISTEM DAN PROSEDUR PENYUSUNAN ANGGARAN PENDAPATAN DAN BELANJA DESA DI DESA KEMBES SATU KECAMATAN TOMBULU KABUPATEN MINAHASA
}

\author{
Dewi Shinta Soeradi ${ }^{1}$, Janjte J. Tinangon ${ }^{2}$, Dhullo Afandi ${ }^{3}$ \\ 1,2,3 Jurusan Akuntansi, Fakultas Ekonomi dan Bisnis Universitas Sam Ratulangi, Jl. Kampus Bahu, Manado, \\ 95115, Indonesia \\ E-mail : ds.soeradi@yahoo.com
}

\begin{abstract}
This research aims to find out and describe about the system and procedure of drafting the Village Budget Kembes Satu Village Tombulu Sub-District Minahasa Regency. The concept of system and procedure used in this research is Standard Operational Procedure and COSO. While the research method used is the qualitative method where the researcher conducts data collection through interview. This research attempts to investigate whether the system and procedure of drafting the Village Budget Kembes Satu Village is in accordance to the regulation Permendagri No. 113 Year 2014. One of the findings of this research is that part of the draft has been done according to the system and procedure, which is included in the ministerial regulation Permendagri No. 113 Year 2014.

Keywords: System and Procedure, Village Budget, Permendagri No. 113 Year 2014
\end{abstract}

\section{PENDAHULUAN}

Dalam tata pemerintahan Negara Kesatuan Republik Indonesia, istilah desa tidak asing lagi. Di Indonesia terdapat 74.754 desa yang didiami lebih dari setengah jumlah penduduk Indonesia. Keberadaan desa dicirikan dengan homogennya, sistem mata pencaharian penduduknya sebagai petani, nelayan, pekebun, peternak, dan lain sebagainya, sehingga muncullah istilah desa nelayan, desa perkebunan dan desa peternakan.Desa atau pedesaan dapat diartikan sebagai daerah yang ada di luar kota. Desa merupakan organisasi pemerintahan resmi yang terendah. Berdasarkan Permendagri No. 113 Tahun 2014, Desa merupakan desa dan desa adat yang kemudian disebut dengan Desa, adalah suatu kesatuan masyarakat hukum yang memiliki batasan wilayah dan hak dalam mengatur dan mengurus kepentingan pemerintah, serta masyarakat desa sesuai dengan prakarsa masyarakat setempat, hak asal usul, dan hak tradisional yang telah dihormati dan diakui dalam sistem pemerintahan NKRI. Pada prinsipnya, keberhasilan penyelenggara pemerintah daerah didasari oleh kewenangan pemerintah daerah tersebut. Dimana dilihat dari otoritas pemerintah daerah dalam merealisasikan pelayanan fungsi keamanan, dan fungsi pemberdayaan kepada masyarakat.(Hoesada J. 2014) menyatakan bahwa desa dan desa adat pada dasarnya melakukan tugas yang hampir sama. Perbedaanya hanyalah dalam pelaksanaan hak asal-usul, terutama menyangkut: pengaturan dan pelaksanaan pemerintahan berdasarkan susunan asli, pengaturan, dan pengurusan ulayat atau wilayah adat, pelestarian nilai sosial budaya desa adat, penyelesaian konflik adat berdasarkan peraturan yang berlaku di dalam desa adat pada wilayah yang sesuai dengan prinsip hak asasi manusia yang mengutamakan penyelesaian konflik dengan cara musyawarah, penyelenggaran sidang perdamaian peradilan desa adat sesuai dengan ketentuan yang diatur dalam peraturan perundang-undangan, pemeliharaan ketenteraman, serta ketertiban masyarakat desa berdasarkan hukum adat yang berlaku di desa adat, dan pengembangan kehidupan hukum adat sesuai dengan kondisi sosial budaya masyarakat setempat. Selain itu, peraturan desa adat disesuaikan dengan hukum adat dan 
norma adat isitiadat yang berlaku di desa adat sepanjang tidak bertentangan dengan ketetntuan peraturan perundang-undang.

\section{TINJAUAN PUSTAKA}

\subsection{Standar Operasional Prosedur}

Menurut Sayuti (2012:2), prosedur merupakan rangkaian metode yang telah dijadikan pola tetap dalam melakukan pekerjaan yang merupakan suatu kebulatan.

\subsubsection{Tujuan Standar Operasional Prosedur}

Secara umum tujuan dari SOP adalah untuk :

1. Agar pegawai dapat menjaga konsistensi serta kinerja baik individu maupun tim dalam organisasi.

2. Agar mengetahui dengan jelas peran dan fungsi tiap-tiap posisi dalam organisasi

3. Menjelaskan tugas atau wewenang serta tanggung jawab dari pegawai yang bersangkutan.

4. Melindungi organisasi (unit) kerja dan petugas/pegawai dari malpraktek atau kesalahan administrasi lainnya.

5. Untuk menghindari hal-hal seperti: kesalahan, kegagalan, keraguan duplikasi maupun inefisiensi.

\subsection{Sistem Pengendalian Internal}

\subsubsection{Pengendalian Internal Menurut COSO}

Pengendalian internal merupakan bagian dari masing-masing sistem yang digunakan sebagai prosedur dan pedoman operasional perusahaan. Definisi pengendalian internal menurut COSO ini dapat dipahami bahwa internal control adaah suatu proses karena hal ini telah menembus kegiatan operasional dalam organisasi dan merupakan bagian yang integral dari kegiatan manajemen.

\subsubsection{TujuanPengendalian Internal}

1. Tujuan Operasi; Yang berkaitan dengan efektivitas dan efisiensi operasi.Bahwa pengendalian internal dimaksudkan untuk meningkatkan efektifitas danefisiensi dari semua operasi perusahaan sehingga dapat mengendalikan biaya yang bertujuan untuk mencapai tujuan organisasi.

2. Tujuan Pelaporan; pengendalian internal dimaksudkan untuk meningkatkan keandalan data atau catatan akuntansi dalam bentuk laporan keuangan dan laporan manajemen sehingga tidak menyesatkan para pengguna laporan serta dapat diuji kebenarannya.

3. Tujuan Ketaatan; Terhadap hukum dan peraturan yang berlaku.Bahwa pengendalian internal dimaksudkan untuk meningkatkan ketaatan entitas terhadap hukum hukum dan peraturan yang telah ditetapkan pemerintah, pembuat aturan terkait, maupun kebijakan kebijakan entitas itu sendiri.

\subsubsection{Unsur-Unsur Pengendalian Internal}

COSO menjelaskan lima unsur pengendalian internal, yaitu sebagai berikut:

1. Control Environment

2. Risk Assessment

3. Control Activities

4. Information And Communication

5. Monitoring Activities"

\subsection{Teori Akuntansi}

\subsubsection{Definisi Akuntansi Pemerintahan}

Sujarweni (2015: 18) menjelaskan bahwa akuntansi pemerintahan adalah akuntansi yang bersangkutan dengan bidang keuangan negara, dari anggaran sampai dengan pelaksanaan dan pelaporannya, termasuk segala pengaruh yang ditimbulkannya. 


\subsubsection{Karakteristik Akuntansi Pemerintahan}

Bachtiar Arif, Iskandar (2002:7) menjelaskan beberapa kriteria akuntansi pemerintahan sebagai berikut:

1.Pemerintah mencacat anggaran pada saat anggaran tersebut dibukukan.

2.Pemerintah tidak berorientasi pada keuntungan oleh karena itu, dalam akuntansi pemerintah tidak terdapat laporan laba/rugi.

3.Akuntansi pemerintahan meggunakan satu atau lebih jenis dana.

4.Akuntansi pemerintahan sifatnya kaku karena sangat tergantung dengan peraturan perundang-undangan.

5.Akuntansi pemerintahan akan membukukan pengeluaran modal

6.Akuntansi pemerintahan tidak membutuhkan perkiraan modal dan laba yang ditahan dalam neraca.

\subsubsection{Syarat Akuntansi Pemerintahan}

PBB telah mengeluarkan pedoman yang berkaitan dengan akuntansi pemerintahan yang kemudian dijelaskan oleh Bachtiar Arif dkk sebagai berikut:

1. Sistem Akuntansi Pemerintahan bisa memenuhi persayaratan UUD, UU dan peraturan lainnya.

2. Sistem Akuntansi Pemerintahan harus disesuaikan bersama dengan klasifikasi anggaran yang telah disetujui dan diintegrasikan pemerintah serta lembaga legislatif.

3. Sistem Akuntansi Pemerintahan harus mengembangkan perkiraan - perkiraan dalam mencatat transaksi-transaksi yang terjadi.

4. Perkiraan yang dibuat merupakan analisis ekonomi dari data keuangan serta klasifikasi jenis transaksi pemerintahan baik pusat maupun daerah.

5. Sistem Akuntansi Pemerintahan sangat memudahkan aparatur negara dalam melalukan pemeriksaan.

\subsection{Penelitian Terdahulu}

Penelitian terdahulu yang penulis jadikan sebagai bahan pertimbangan dalam melakukan penelitian di Desa Kembes Satu Kecamatan Tombulu Kabupaten Minahasa. Penelitian yang dilakukan oleh Juhnita Rati tahun 2016, tentang sistem penganggaran dan belanja desa (APBDes) Teratak Buluh Kecamatan Siak Hulu Kabupaten Kampar Tahun 2014 untuk mengetahui dampak dengan cara menganalisis proses perencanaan APBDes tahun 2014.

\section{METODE PENELITIAN}

\subsection{Jenis Penelitian}

Penelitian ini menggunakan penelitian kualitatif deskriptif dimana penelitimelakukan dengan teknik pengumpulan data melalui wawancara dan mencari tambahan dari sumber tertulis seperti dokumen Peraturan Pemerintah serta menggambarkan atau menjelaskan suatu kondisi dengan "apa adanya" mengenai suatu gejala, variabel atau keadaan. Jenis penelitian ini hanya menggambarkan secara sistematis mengenai fakta, situasi dan aktivitas yang berkaitan dengan pengelolaan keuagan desa menurut Permendagri No. 113 Tahun 2014.

\subsection{Waktu dan Tempat Penelitian}

Penelitian ini dilaksanakan di Desa Kembes Satu, Kecamatan Tombulu, Kabupaten Minahasa tepatnya berada di Jl. Raya Kembes Satu, Tombulu, Kota Manado, Sulawesi Utara. Waktu penelitian dilakukan sesuai keperluan yaitusekitar 3 bulan.

\subsection{Prosedur Penelitian}

Mengidentifikasi masalah, menentukan objek penelitian, penyusunan proposal penelitian, pengumpulan data, menganalisis dan mengolah data, hasil penelitian, membuat kesimpulan dan memberikan saran. 


\subsection{Metode Analisis}

Metode analisis yang digunakan dalam penelitian ini adalah metode analisis deksriptif yang dimulai dengan langkah mengumpulkan dan menyaring keterangan-keterangan yang diperoleh secara menyeluruh dan detail, kemudian diuraikan sehingga diperoleh gambaran yang jelas. Adapun data-data yang diperoleh berupa Pengelolaan Keuangan Desa menurut Permendagri No. 113 Tahun 2014 dan Pertanggungjawaban Keuangan Desa, kemudian dianalisis penerapannya sehingga dapat ditarik suatu kesimpulan. Analisis akan dilakukan sejak thapaan penyusunan kua/ppas sampai dengan penentapan apbdes sehingga bahasan yang dilkakukan yakni bahsa terhadap penyusunan KUA/PPAS,

1. Analisis Sistem dan Prosedur Penyusunan KUA/PPAS

2. Analisis Sistem dan Prosedur Penyusunan RAPBDes

3. Analisis Sistem dan Prosedur Penetapan APBDes

Mengingat keterbatasan waktu analisis akan dilakukan proses penyusunan anggaran tahun 2016-2017. Alat analisis penyusunan yang digunakan untuk menguji memadai tidaknya sistem penyusunan anggaran di Desa Kembes Satu Kabupaten Minahasa yakni menggunakan COSO dalam mengevaluasi sistem pengendalian internal dalam setiap prosedur yang di maksud. Selanjutnya, untuk menguji kepatuhan terhadap peraturan perundang-undangan maka setiap prosedur yang ada dibandingkan dengan prosedur yang diatur dalam Permendagri No.113 Tahun 2014.

\section{HASIL ANALISIS DAN PEMBAHASAN}

\subsection{Hasil analisis}

\subsubsection{Sistem dan Prosedur Penyusunan KUA/PPAS di Desa Kembes Satu}

Adapun rancangan KUA/PPAS yang ada di Desa Kembes Satu disusun dengan tahapan sebagai berikut:

a. Menentukan skala prioritas pembangunan daerah

Tabel 4.1 Menentukan Skala Prioritas Pembangunan Desa

\begin{tabular}{|c|c|c|c|}
\hline NO & BIDANG/KEGIATAN & TUJUAN & LOKASI \\
\hline \multirow[t]{2}{*}{$A$} & 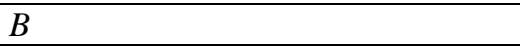 & $C$ & $D$ \\
\hline & \multicolumn{3}{|l|}{ Penyelenggaraan Pemerintahan } \\
\hline 1 & Penghasilan Tetap dan Tunjangan & Meningkatkan Kesejahteraan aparatur & Desa Kembes Satu \\
\hline 2 & Operasional Desa & Meningkatkan kinerja aparatur & Desa Kembes Satu \\
\hline 3 & Operasional BPD & Meningkatkan kinerja BPD & Desa Kembes Satu \\
\hline 4 & Pembuatan Profil Desa & Meningkatkan Pelayanan Masyarakat & Desa Kembes Satu \\
\hline 5 & Penyelenggaraan Musyawarah Desa & $\begin{array}{l}\text { Meningkatkan } \\
\text { Masyarakat }\end{array}$ & Desa Kembes Satu \\
\hline 6 & Penyelenggaraan perencanaan Desa & $\begin{array}{l}\text { Penyusunan } \\
\text { RPJMDes dan Perdes }\end{array}$ & Desa Kembes Satu \\
\hline 7 & Pengelolaan Informasi Desa & $\begin{array}{l}\text { Meningkatkan } \quad \text { Pelayanan } \\
\text { Masyarakat }\end{array}$ & Desa Kembes Satu \\
\hline \multirow[t]{2}{*}{8} & Pendataan Desa & Administrasi Desa & Desa Kembes Satu \\
\hline & \multicolumn{3}{|l|}{ Pelaksanaan Pembangunan } \\
\hline 1 & Pemeliharaan/Rehab jalan & $\begin{array}{ll}\text { Peningkatan } & \text { Sarana } \\
\text { Perhubungan } & \\
\end{array}$ & Desa Kembes Satu \\
\hline 2 & Pembangunan jalan perkebunan & $\begin{array}{ll}\text { Peningkatan } & \text { Sarana } \\
\text { Perhubungan } & \\
\end{array}$ & Desa Kembes Satu \\
\hline 3 & Gorong-gorong & $\begin{array}{ll}\text { Peningkatan } & \text { Sarana } \\
\text { Perhubungan } & \\
\end{array}$ & Desa Kembes Satu \\
\hline 4 & Betonisasi Jalan (setapak) & $\begin{array}{ll}\text { Peningkatan } & \text { Sarana } \\
\text { Perhubungan } & \\
\end{array}$ & Desa Kembes Satu \\
\hline 6 & Talud & Penahan Tanah & Desa Kembes Satu \\
\hline \multirow[t]{2}{*}{7} & Saluran Drainase & Meningkatkan Sanitasi & Desa Kembes Satu \\
\hline & \multicolumn{3}{|l|}{ Pembinaan Kemasyarakatan } \\
\hline
\end{tabular}


Jurnal Riset Akuntansi Going Concern 13(3), 2018, 144-156

\begin{tabular}{|c|c|c|c|}
\hline NO & BIDANG/KEGIATAN & TUJUAN & LOKASI \\
\hline$A$ & 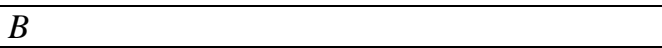 & $C$ & $D$ \\
\hline 1 & Kegiatan Pembinaan LPMD & $\begin{array}{ll}\text { Peningkatan } & \text { Kinerja } \\
\text { LPMD/KPMD } & \end{array}$ & Desa Kembes Satu \\
\hline 2 & Kegiatan Pembinaan Karang Taruna & $\begin{array}{lll}\text { Peningkatan } & \text { Kinerja } & \text { Karang } \\
\text { Taruna } & & \\
\end{array}$ & Desa Kembes Satu \\
\hline 3 & Kegiatan Pembinaan Tim Penggerak PKK & Peningkatan Kinerja TP. PKK & Desa Kembes Satu \\
\hline 4 & $\begin{array}{l}\text { Kegiatan Penyelenggaraan Ketentraman dan } \\
\text { Ketertiban }\end{array}$ & Untuk Keamanan Desa & Desa Kembes Satu \\
\hline 5 & Pengadaan Sarana dan Prasarana Olahraga & Peningkatan Sarana Olahraga & Desa Kembes Satu \\
\hline \multirow[t]{2}{*}{6} & Pemberian Bantuan Sosial & $\begin{array}{ll}\text { Peningkatan } & \text { Kesejahteraan } \\
\text { Masyarakat } & \end{array}$ & Desa Kembes Satu \\
\hline & \multicolumn{3}{|l|}{ Pemberdayaan Masyarakat } \\
\hline 1 & $\begin{array}{l}\text { Pelatihan Program pemberdayaan masyarakat } \\
\text { dan Desa }\end{array}$ & $\begin{array}{l}\text { Meningkatkan Pengetahuan } \\
\text { bagi Tim Penyusun RPJMDes }\end{array}$ & Desa Kembes Satu \\
\hline 2 & Pelatihan Aset dan Keuangan Desa & $\begin{array}{l}\text { Meningkatkan } \\
\text { bagi KPMD }\end{array}$ & Desa Kembes Satu \\
\hline 3 & Peningkatan Kapasitas Pengurus BUMDES & $\begin{array}{l}\text { Meningkatkan Pengetahuan } \\
\text { bagi Pengurus BUMDES }\end{array}$ & Desa Kembes Satu \\
\hline 4 & Kegiatan Perlombaan Desa & $\begin{array}{l}\text { Meningkatkan Pengetahuan } \\
\text { bagi kelompok usaha }\end{array}$ & Desa Kembes Satu \\
\hline 5 & $\begin{array}{l}\text { Peningkatan Kapasitas Kelompok Perempuan } \\
\text { (PKK) }\end{array}$ & $\begin{array}{l}\text { Meningkatkan } \quad \text { Pengetahuan } \\
\text { bagi Perempuan }\end{array}$ & Desa Kembes Satu \\
\hline 6 & Peningkatan Kapasitas Bagi Hukum Tua & $\begin{array}{ll}\text { Meningkatkan } & \text { Pengetahuan } \\
\text { bagi Hukum Tua } & \end{array}$ & Desa Kembes Satu \\
\hline 7 & Peningkatan Kapasitas Bagi Perangkat Desa & $\begin{array}{l}\text { Meningkatkan Pengetahuan } \\
\text { bagi Perangkat Desa }\end{array}$ & Desa Kembes Satu \\
\hline 8 & Peningkatan Kapasitas bagi BPD & $\begin{array}{l}\text { Meningkatkan Pengetahuan } \\
\text { bagi BPD }\end{array}$ & Desa Kembes Satu \\
\hline 9 & Pelatihan SISKEUDES & $\begin{array}{l}\text { Meningkatkan Pengetahuan } \\
\text { bagi Perangkat Desa }\end{array}$ & Desa Kembes Satu \\
\hline 10 & Penguatan Permodalan BUMDES & $\begin{array}{l}\text { Meningkatkan } \quad \text { Kesejahteraan } \\
\text { Masyarakat }\end{array}$ & Desa Kembes Satu \\
\hline 11 & Pengelolaan POSYANDU & $\begin{array}{l}\text { Meningkatkan } \\
\text { Masyarakat }\end{array}$ & Desa Kembes Satu \\
\hline 12 & $\begin{array}{l}\text { Pemeliharaan Lingkungan dan kebersihan } \\
\text { desa }\end{array}$ & Meningkatkan kebersihan Desa & Desa Kembes Satu \\
\hline 13 & Budidaya Tanaman (green House) & Meningkatkan Keindahan Desa & Desa Kembes Satu \\
\hline
\end{tabular}

(Sumber:Desa Kembes Satu, 2018)

b. Menentukan prioritas program untuk masing-masing urusan

Persediaan pada Kantor Wilayah Kementerian Agama Provinsi Sulawesi Utara terdiri dari persediaan alat tulis kantor, alat listrik dan elektronik (lampu pijar dan batrei), materai, peralatan kebersihan dan bahan pembersih serta bahan bakar solar.

b.Peralatan dan mesin

Peralatan dan mesin pada kantor wilayah kementerian agama diklasifikasikan sesuai dengan jenisnya seperti alat perkantoran, komputer/leptop, meja, kursi, printer dan lemari.

c.Gedung dan Bangunan

Gedung dan bangunan dapat diklasifikasikan menurut jenisnya, sepertigedung perkantoran, rumah dinas, bangunan tempat ibadah, menara, monumen/bangunan bersejarah, gudang, gedung museum.

\subsubsection{Sistem dan Prosedur Penyusunan RAPBDes}

AW.Widjaja, 1996 mendefinisikan APBDes sebagai Anggaran Desa yang terdiri dari anggaran rutin serta anggaran pembangunan. RAPBDes adalah suatu daftar rencana pendapatan dan pengeluaran/pembelanjaan anggaran desa pada tahun tertentu setiap tahun 
akan dibuat. Di Desa Kembes Satu RAPBDes yang akan disusun melihat daftar atau rencana pendapatan dan pengeluaran yang akan dilakukan untuk program/kegiatan yang akan dilaksanakan.

\subsubsection{Sistem dan Prosedur Penetapan APBdes}

Dalam rangka mewujudkan pengolahan dana desa yang transparan, akuntabel dan partisipatif, tertib dan disiplin sesuai dengan Permendagri No. 113 Tahun 2014 dan berdasarkan ketentuan Undang-undang No. 6 Tahun 2016 Tentang Desa maka pemerintah harus melaksanakan musyawarah desa untuk penetapan APBDes. Adapun kegiatan musyawarah desa dimulai dengan pembukaan protocol dan dilanjutkan dengan menyanyikan lagu kebangsaan Indonesia Raya oleh seluruh undangan yang hadir. Selanjutnya dilakukan pembacaan program-program dan kegiatan-kegiatan yang akan disahkan dan disampaikan oleh sekretaris desa Kembes Satu.

\subsection{Pembahasan}

\subsubsection{Analisis Sistem dan Prosedur Penyusunan KUA/PPAS Desa Kembes Satu}

Pembahasan merupakan isi dari hasil analisis data dan fakta yang peneliti dapatkan di lapangan serta disesuaikan dengan teori yang peneliti gunakan. Dalam menganalisis Sistem dan Prosedur KUA/PPAS dibagi ke dalam dua bagian yaitu analisis sistem dan prosedur pengendalian internal dan analisis kepatuhan. Dalam penelitian ini dilihat berdasarkan prinsip-prinsip yang harus ditetapkan dalam Sistem dan Prosedur menurut COSO yang meliputi beberapa hal, sebagai berikut:

\section{Control Environment \\ 2. Risk Assessment \\ 3. Control Activities \\ 4. Information And Communication \\ 5. Monitoring Activities"}

Sistem dan Prosedur di Desa Kembes Satu Kabupaten Minahasadapat diketahui berjalan dengan baik atau tidaknya berdasarkan 5 (lima) prinsip yang telah disebutkan. Masingmasing prinsip diuraikan sebgai indikator-indikator untuk mempermudah dan memahami aspek-aspek yang akan diteliti.

\subsubsection{Analisis Sistem Pengendalian Internal atas Penyusunan KUA/PPAS di Desa Kembes Satu}

Sistem pengendalian internal menurut COSO (Committee of Sponsoring Organization of The Treadway Commission) ada 5 pengendalian yang digunakan untuk menganalisis, yakni:

1. Control Environment (Lingkungan Pengendalian)

Lingkungan pengendalian adalah rangkaian standar, proses dan struktur yang menjadi dasar dalam penyelenggaran pengendalian inter di seluruh organisasi.

Lingkungan pengendalian yang ada di Desa Kembes Satu yang mencakup integritas dan etika dalam organisasi pememrintahan yang ada di Desa ini sangat mampu dalam melaksanakan program/kegiatan yang sudah disusun. Kepala desa serta pemerintahan yang ada disana juga sangat kompeten dalam melaksankan program yang akan dilaksanakan, serta kejelasan dalam mengawasi program/kegiatan yang sudah direncanakan, insentif serta memberikan imbalan untuk mendorang kegiatan/program yang sudah direncanakan agar lingkungan pengendalian yang akan dihasilkan mampu memberi dampak yang luas terhadap pengendalian inter secara keseluruhan di masyarakat Desa Kembes Satu agar nantinya dimasa yang akan datang masyarakat Desa Kembes Satu bisa merasakan dampak yang sudah dilakukan oleh pemerintah Desa Kembes Satu. Lingkungan Pengendalian mensyaratkan 7 hal yang harus terpenuhi apabila lingkungan pengendalian itu dikatakan memadai atau tidak. 7 hal yang dimaksud ialah; 
1) Integritas dan Nilai Etika; Integritas dan Nilai Etika mengsyaratkan bahwa prosedur ini menjamin bahwa pelaksanaan sistem ini dilaksanakan oleh orang-orang yang memiliki integritas yang tinggi dan memiliki keteladanan dan mempertanggungjawabkan yang cukup. Hal ini setelah ditelusuri dalam proses yang terjadi di dalam penyusunan KUA/PPAS di Desa Kembes Satu tidak ditemukan adanya aturan/perangkat aturan yang mengharuskan bahwa orang yang terlibat disini harus memiliki integritas seperti; menyusun dan menetapkan aturan perilaku dan memberikan keteladanan pelaksanaan perilaku pada setiap perangkat desa yang ada di Desa Kembes Satu.

2) Komitmen dan Kompetensi; Komitmen dan Kompetensi yang akan duduk diharapkan memiliki keahlian, tidak dibuat suatu pengendalian/aturan sehingga otomatis yang terlibat di dalam proses ini tidak ditentukan. Dan kompetensi yang harus minimal ada tidak ditentukan. Oleh sebab itu, akibat sebab tidak adanya komitmen dan kompetensi ini menggambarkan suatu lingkungan pengendalian yang tidak memadai dari sisi komitmen dan kompetensi.

3) Kepemimpinan yang Kondusif; kepemimpinan yang konduif ini yang ada di Desa Kembe Satu adalah untuk mempertimbangkan risiko dalam mengambil keputusan dan merespon secara positif terhadap pelaporan yang berkaitan dengan keuangan, penganggaran, program dan kegiatan. Sehingga dalam Lingkungan pengendalian, kepemimpinan yang kondusif ini menggambarkan suatu pengendalian yang hampir mendekati memadai.

4) Falsafah dan Gaya Operasi; falsafah dan gaya operasi ini mengsyaratkan setidaknya ada beberapa hal yang dinyatakan memadai tidaknya. Perangkat Desa yang ada di Desa Kemes Satu mempunyai peran yang besar dalam memberikan lingkungan pengendalian yang baik dalam suatu organisasi sehingga fasafah dan gaya operasi ini dinyatakan memadai karena mengikuti unsure yang terdapat dalam falsafah dan gaya operasi yang terdapat dalam lingkungan pengendalian.

5) Struktur Organisasi; struktur organisasi ini menggambarkan suatu hubungan wewenang dan tangggungjawab sehingga Kepala Desa Kembes Satu serta Perangkat desa yang ada dapat memberikan kontribusi bagi lingkungan pengendalian baik dalam memberikan kerangka secara menyeluruh bagi perencanaan, pelaksanaan dan pengendalian operasi. Sehingga dalam struktur organisasi ini peneliti menyatakan memadai karena Pemerintah Desa Kembes Satu mempunyai kontribusi dalam hal tanggungjawab.

6) Pendelegasian Wewenang dan Tanggungjawab; berupa memorandum tertulis mengenai kebijakan-kebijakan, aturan, deskripsi pekerjaan dan sebagainya. Wewenang diberikan dengan tingkat tanggungjawab yang tepat dalam rangkan pencapaian tujaun Pemerintah Desa Kembes Satu.

7) Kebijakan dan Praktek; penetapan kebijakan dan prosedur sejak rekrutmen sampai dengan pemberhentian.

Dari 7 hal diatas terdapat setidaknya 3 unsur yang tidak memadai. Yaitu, Integritas dan Nilai Etika, Komitmen dan Kompetensi dan Kepemimpinan yang Kondusif. Dengan tidak terpenuhinya unsure-unsur ini menggambarkan suatu lingkungan pengendalian yang belum/tidak memadai. Agar lingkungan pengendalian ini dikatakan memadai dan dapat berjalan efektif dibuat salah satu standar prosedur tentang syarat-syarat orang yang harus terlibat.

2. Risk Assessment (Penilain Risiko)

Penilain resiko melibatkan proses yang dinamis yang terjadi berulang-ulang (iterative) untuk mendidentifikasi dan menganalisis risiko terkait pencapain tujuan.Berdasarkan hasil penelitian yang peneliti dapatkan di lapangan. Menurut peneliti risiko adalah faktor 
utama yang berpotensi untuk menghambat tercapainya tujuan. Hal utama yang dalam penilain risiko ini adalah adanya kesadaran dari Kepala Desa dan pimpinan lainnya dalam pemerintahan yang ada di Desa kembes Satu bahwa setiap kegiatan pekerjaan, terutama kegiatan pokok pekerjaan, memiliki risiko yang harus dikelola. Pengelolaan akan tergantung pada tingkat risiko yang dihadapi. Mekanisme yang ditetpakan untuk mengidentifikasi, menganalisis, mengelola risiko-risiko yang berkaitan dengan berbagai kegiatan/program. Yang peeliti dapati di Desa Kembes Satu yang menjadi penghalang terhambatnya yaitu:

1) Mentolelir risiko misalnya menggunakan peralatan yang ada karena keterbatan sumber daya yang terdapat di Desa Kembes Satu.

2) Menghilangkan risiko dengan mengubah jenis pekerjaan karena pekerjaan tersebut memiliki risiko yang besar dan tidak dapat dilakukan.

3) Membangun jalan raya yang hanya menggunaka bahan seadanya demi menutupi jalan yang rusak (berlubang) meskipun hanya bertahan tidak lama.

3. Control Activities (Kegiatan Pengendalian)

Kegiatan pengendalian mencakup kegiatan-kegiatan yang dilakukan melalui kebijakan dan prosedur untuk membantu memastikan dilaksanakannya arahan manajemen dalam rangka meminimalkan risiko atas pencapain tujuan.

Berdasarkan hasil penenlitian yang peneliti dapatkan dari informan yakni kegiatan pengendalian yang ada di Desa Kembes Satu yaitu agar terwujudnya manajemen yang sudah di rencanakan program/kegiatan, kebijkan dan prsedur-prosedur yang sudah di tetapkan untuk membantu terwujudnya tujuan yang akan dicapai. Di Kembes Satu, salah satu tujuan yang sudah terwujudnya adalah pembangunan Saluran Drainase untuk meningkatkan sanitasi, gorong-gorong untuk meningkatkan saran perhubungan serta serta pembangunan jalan perkebunan untuk mempermudah para petani dlaam menjalankan tugasnya dan pembuatan talud untuk menahan tanah.

4. Information and Communication (Informasi dan Komunikasi)

Organisasi memerlukan informasi demi terselenggaranya fungi pengendalian intern dalam mendukung pencapian tujuan. Hal tersebut diperlukan agar komponen pengendalian intern yang lain berfungsi dengan baik sebagaimana mestinya. Komunikasi internal harus menjadi sarana diseminasi informasi didalam organisasi, baik dari atas kebawah, dari bawah ke atas, maupun lintas fungsi.

Berdasarkan hasil penelitian yang peneliti dapatkan bahwa Informasi dan komuniaksi itu sangat penting demi terwujudnya tujuan program/kegiatan yang sudah ditetapkan. Komunikasi dan informasi menurut kepala desa Kembes Satu adalah untuk memperoleh entitas dan menukar informasi yang diperlukan untuk melaksanakan, mengelola, dan mengedalikan kegiatan operasi yang sedang berlangsung. Informasi dan komunikasi ini sangat diperlukan dalam organisasi kepemrintahan yang ada di Desa Kembes Satu. Jika tidak ada informasi dari Kepala desa dalam melaksanakan kegiatan/program yang sedang berlangsung maka kegiatan/program itu tidak dapat berjalan.

5. Monitoring Activities (Kegiatan Pemantauan)

Komponen ini merupakan satu-satunya komponen yang berubah nama. Sebelumnya komponen ini hanya disebut Pemantauan (monitoring). Perubahan ini dimaksudakan untuk memperluas persepsi pematauan sebagai rangkain aktivitas yang dilakukan sendiri dan juga sebagai bagian dari masing-masing 4 (empat) komponen pengendalian intern lainnya.Berdasarkan hasil penelitian proses ini diperlukan untuk memantau kegiatan/program apa yang sedang Kembes Satu laksanakan. Entah ini program keci atau besar perlu pemantauan agar dapat bertujuan untuk meningkatkan dan untuk menilai kinerja sistem sepanjang waktu yang sedang Desa Kembes Satu laksanakan. Kegiatan pemantaun ini menurut Kepala Desa Kembes Satu, Audi Kindnagen, ini dijalankan 
melalui aktivitas pemantauan yang terus-menerus, evaluasi yang terpisah, atau kombinasi dari kedua-duanya agar program/kegiatan yang sudah diremcakan dapat berjalan dengan baik meskipun ada hambatannya.

\subsubsection{Analisis Kepatuhan Sistem dan Prosedur Penyusunan KUA/PPAS}

Menurut aturan yang ada di dalam Permendagri No. 113 Tahun 2014 berdasarkan hasil penelitian yang peneliti dapatkan dari Informan yang ada di Desa Kembes Satu Kabupaten Minahasa. Pada tahap penganggaran, secara proses terdiri dari proses penyusunan KUA/PPAS, proses penyusunan RAPBDes dan Proses penetapan APBDes.

\subsubsection{Analisis Sistem dan Prosedur Penyusunan RAPBDes}

Setelah rancangan KUA-PPAS disepakati menjadi KUA-PPAS maka selanjutnya dilakukan penyusunan RAPBDes. Dimana menurut Permendagri No. 13 Tahun 2006 RAPBDes disampaikan ke DPRD paling lambut bulan oktober. Proses penyusunan RAPBDes di awali dengan dikeluarkanya surat ederan.

RAPDES merupakan dokumen yang memuat tentang rincian anggaran pendapatan dan anggaran belanja APBDes dalam satu tahun anggaran. Sehingga semua penggunaan keuangan desa masing-masing pos anggaran harus disesuaikan dengan dokumen ini agar tidak terjadi penyimpangan anggaran yang tidak sesuai dengan peraturan perundangundangan yang berlaku. RAPBDes juga berfungsi sebagai kontrol dalam penggunaan keuangan desa, sehingga pelaksana/pengguna anggaran tidak bisa semena-mena dalam menggunakan keuangan desa, untuk kepentingan pribadi atau kepentingan lain yang tidak sesuai dengan peraturan perundang-undangan sehingga mencegah terjadinya korupsi. Dengan berlakunya Undang-undang Nomor 6 Tahun 2014 tentang Desa, maka format RAPBDes telah berubah dan dalam penyusunannya sesuai dengan Permendagri Nomor 113 Tahun 2014, sehingga pada lampiran Perdes RAPBDes tidak lagi ada format Ringkasan Badan Penjabaran APBDes melainkan format Rincian Struktur APBDes dan Rencana Anggaran Biaya (RAB).

\subsubsection{Analisis Sistem Pengendalian Internal Penyusunan RAPBDes}

Menurut COSO ada 5 pengendalian internal yang peneliti gunakn untuk menganalisi sistem pengendalian internal dalam penyusunan RAPBDes.

1. Lingkungan Pengendalian (Control Environment)

Lingkungan pengendalian ini dimana kepala desa bertanggung jawab untuk menyatakan dengan jelas bahwa setiap program yang disusun harus berjalan dengan sesuai rencana dan menunujukkan nilai-nilai integritas dan kegiatan yang tidak etis yang tidak dapat untuk ditoleransi. Jadi yang peneliti dapatkan di Desa Kembes Satu bahwa, lingkungan pengendalian ini yang menduduki puncaknya ialah, Kepala Desa. Jika ada hal yang menyimpang dari program/kegiatan yang sudah terususn makan kepala desa akan memberikan sanksi yang pantas.Lingkungan pengendalian tercermin dari suasana dan kesan yang diciptakan oleh Kepala Desa Kembes Satu, beserta dengan para jajarannya yang ada di Desa Kembes Satu dalam memerintah masyarakat yang ada. Puncak mengenai pentingnya pengendalian internal dan standar perilaku yang diharapkan pemerintah desa Kembes Satu, mempertegas harapan atau ekspektasi itu pada berbagai tingkatan organisasi. Sub-komponen lingkungan pengendalian mencakup integritas dan nilai etika yang dianut oleh Kepala Desa Kembes Satu dan jajaran-jajarannya serta masyarakat Kembes Satu yang ada menjadikan kepala desa mampu melaksanakan tanggung jawab tata kelola; struktur organisasi dan pembagian wewenang serta tanggung jawab untuk mendorong akuntabilitas kinerja.

2. Penilaian Risiko (Risk Assessment)

Penilaian risiko yang bisa terjadi dalam penyusunan RAPDes ini dimana munculnya perbedaan pendapat/usulan yang akan kita dapati dalam Musrembang yang akan berdampak merugikan bagi pencapaian tujuan. Risiko yang dihadapi Pemerintah setempat bisa bersifat internal (berasal dari dalam) ataupun eksternal (bersumber dari 
luar). Salah satu prakondisi bagi penilaian risiko adalah penetapan tujuan yang saling terkait pada berbagai tingkat yang ada. Kepala Desa serta pemerintah yang ada di Desa Kembes Satu harus menetapkan tujuan dalam katagori operasi, pelaporan, dan kepatuhan dengan jelas sehingga risiko-risiko terkait bisa diidentifikasi dan dianalisa. Kepala Desa serta pemerintah yang ada juga harus mempertimbangkan kesesuaian tujuan dengan kegiatan/program yang sudah sudah/akan disusun. Penilaian risiko mengharuskan untuk memperhatikan dampak perubahan lingkungan eksternal serta perubahan model itu sendiri yang berpotensi mengakibatkan ketidakefektifan serta hambatan-hambatan yang dapat menghalangi proses terjadinya kegiatan/program yang akan dilaksanakan. Penilaian risiko ini sangat penting dalam mewujudkan apa yang sudah diprogamkan. Baik buruknya kita harus dengar dan terima untuk kemajuan bagi masyarkat yang ada di Desa Kembes Satu.

3. Kegiatan Pengendalian (Control Activities)

Sebagai komponen ketiga dalam model COSO, kegiatan pengendalian (control activities) merupakan salah satu komponen yang penting dalam pengendalian internal pada tahun 1999,.kegiatan pengendalian ini yang diterapkan di Desa Kembes Satu adalah bagaimananya dilakukan review atas kinerja yang dilakukan oleh Pemerintah Kembes Satu dengan membandingkan kinerja dengan tolok ukur kinerja yang sudah ditetapkan. Pembinaan sumber daya manusia sekurang-kurangnya harus;

1.Mengkomunikasikan visi, misi, tujuan, nilai dan strategi untuk masyarakat Desa Kembes Satu;

2.Membuat strategi perencanaan dan pembinaan sumber daya manusia yang mendukung pencapaian visi dan misi;

3.Membuat ringkasan mengenai jabatan, prosedur rekrutmen, program pendidikan dan pelatihan pegawai, sistem kompensasi, fasilitas masyarakat serta program kesejahteraan.

Pemerintah Kepala Desa Kembes Satu wajib menetapkan, mengimplementasikan dan mengkomunikasikan pengendalian fisik terhadap aset kepada seluruh masyarakatnya, sedikitnya melalui:

a.Rencana identifikasi, kebijakan, dan prosedur pengamanan fisik;

b.Rencana pemulihan setelah bencana alam yang terjadi.

4. Informasi dan Komunikasi (Information and Communication)

Informasi dan komunikasi yang bersangkutan harus didentifikasi, tergambar dan terkomunikasi dengan baik dalam sebuah form dan timeframe yang memungkinkan orang-orang menjalankan tanggung jawabnya.Informasi dan komunikasi yang terdapat dalam kepemerintahan Desa Kembes Satu harus terjalin dengan baik. Tanpa adanya komunikasi kegiatan yang sudah tersusun tidak akan berjlan dengan baik. RAPBDes yang sudah di program/kegiatannkan di Kembes Satu akan sangat baik bila semua yang akan terlibat berkomunikasi serta memberikan informasi agar tidak ada yang salh dalam menjalankan aktifitas tersebut. Tersusunnya RAPBDes di Kembes Satu karena adanya komunikasi (Musrembang) yang diadakan pada tanggal 28 Juni 2016 di Kantor Hukum Tua sebagaimna mestinya. Bagian ke empat (4) ini menurut COSO sangatlah penting untuk piha-pihak lain yang akan membantu dalam pembangunan yang akan dilaksanakan nanti. Bagi masyarakat Desa Kembes Satu, karena adanya komunikasi serta informasi-informasi dari Pemerintah Kembes Satu kepada Masyarakat Kembes Satu maka masyrakat akan sangat senang dalam hal membantu serta memberikan masukan dalam Musrembang yang dilaksnakan pada tanggal yang sudah tercantumkan. Musrembang dalam rangka Penyusunan Rencana Anggaran Pendapatan dan Belanja Desa adalah untuk menyusun anggaran serta kegiatan/program pembangunan desa yang dilaksanakan di Desa Kembes Satu. 
Kepala Desa, Audi Kindangen mengharpakan kiranya informasi-informasi yang diberikan kepada masyrakat Desa Kembes Satu sangat membantu dalam penyusunan RAPBDes ini.

5. Kegiatan Pemantauan (Monitoring Activities)

Yang terakhir dalam sistem pengendalian internal menurut COSO ialah kegaiatan pemantauan. Pemantauan ini adalah bertujuan untuk memantau atau mengawasi setiap kegiatan atau pergerakan dari setiap kegiatan/program yang sudah disusun dalam RAPBDes dari waktu ke waktu. Akan sangat baik jika Kepala Desa Kembes Satu terjun langusung dalam mengawasi kegiatan/program yang sudah tersusun didalam RAPBDes.

\subsubsection{Analisis Sistem Pengendalian Internal Kepatuhan RAPBDes}

Pemerintah desa di wilayah Kecamatan Tombulu Kabupaten Minahasa secara umum memiliki sumber daya yang masih minim, sehingga berpengaruh pada hasil dari proses pengelolaan keuangan yang dibuat hanya memuat Rancangan Anggaran Pendapatan dan Belanja Desa (APBDesa). Menurut permendagri No. 113 Tahun 2014 menyatakan dalam Pasal 20 ayat (2) bahwa sekretaris desa menyampaikan rancangan peraturan tentang desa ke kepala desa. pasal 21 ayat (2) Bupati/Walikota menetapkan hasil evaluasi Rancangan APBDesa sebagaimana dimaksud pada ayat (1) paling lama 20 (dua puluh) hari kerja sejak diterimanya Rancangan Peraturan Desa tentang APBDesa.

\subsubsection{Analisis Sistem dan Prosedur Penetapan APBDES}

Anggaran Pendapatan dan Belanja Desa atau biasa yang disebut dengan APBDes dalam penentapannya dilakukan Musyawarah Desa. sebelum ditetapakn penetapan APBDes, pemerintah yang ada di Desa Kembes Satu harus melakukan musyawarah desa atau musrembang. Sbelum peneapan APBDes pemerintah Desa Kembes Satu seperti yang peneliti bahas bahwa aka nada penyusunan RAPBDes sebelum disetujuinya APBDes.

APBDes yang ada di Dewsa Kembes Satu akan sangat teratur jika berjalan sesuai dengan program/kegiatan yang telah di susun dalam Musyawarah Desa yang ada di Desa Kembes Satu, Kecamatan Tombulu, Kabupaten Minahasa.

Senin, 20 Maret 2017 bertempat di Balai desa Kembes Satu Pukul 19.00 wita telah dilaksnakan Musyawarah Desa Penetapan Rancangan Peraturan tentang Anggaran Pendapatan dan Belanja Desa (APBDes).

Adapun peserta musyawarah desa pada kesempatan ini ada Kepala Desa kembes Satu beserta dengan Perangkat desa, BPD dan Anggota, Masyarakat Desa dan turut hadir dari musyawarah tersebut Pendamping Desa Kembes Satu.

\subsection{Analisis Pengendalian Internal APBDes}

Pengendalian internal yang ada di Desa Kembes Satu dalam Penetapan APBDes adalah bagaimana Kepala Desa Kembes Satu dalam menjalankan kegiatan/Program yang sudah tersusun harus mengikuti Prosedur yang sudah ditentukan. Rangkaian standar, proses dan dan struktur yang menjadi tolak ukur dan penentapan APBDes ini adalah pengendalian intern atau pengendalian lingkungan untuk menciptakan irama dalam kepemerintahan yang ada di Desa Kembes Satu. Pentingnya pengendalian intern dan standar perilaku yang diharapkan mencakup integritas dan dan nilai etika yang dianut oleh kepemerintahan yang ada di Desa Kembes Satu. Lingkungan pengendalian yang dihasilkan akan berdampak luas terhadapa sistem pengendalian intern secara keseluruhan. Tentu saja dalam penetapan APBDes ini ada masalah-masalah serta risiko yang dihadapi oeh pemerintah setempat yang ada di Desa Kembes Satu. Masalah atau risiko yang dihadapi oleh Desa Kembes Satu misalnya penyakuran dana belum sampai ke desa sedangkan program/kegiatan yang sudah disusun sudah pada tanggalnya yang akan dilaksanakan kegiatan/program. Masalah-masalah yang ada juga bisa dari luar atau dari dalam tergantung bagaimana kita menyikapinya. Pemerintah juga harus menetapkan tujuan dari pelaporan dan kepatuhan dengan jelas agar 
risiko-risko atau masalah terkait bisa diidentifikasi. Kegiatan Pengendalian mencakup tindakan-tindakan yang ditetapkan melalaui kebijakan-kebijakan dan prosedur untuk membantu memastikan dilaksanakannya arahan dari Pemerintah desa Kembes Satu dalam rangka meminimalkan risiko atas pencapaian tujuan. Kegiatan pengendalian yang ada di Desa Kembes Satu seperti yang dikatakan oleh Sekretaris Desa, pada semua tingkatan kegiatan/program;" torang $k w$ adek setiap kegiatan ato program ada yang bersifat manual ada yang nyanda. Contohnya dang depe kegiatan/program mencakup verivikasi dll sebagainya. "Selanjutnya informasi dan komunikasi yang ada di desa Kembes Satu harus diperlukan demi terselenggaranya fungsi pengendalian intern dalam mendukung pencapaian tujuan. Pemerintah harus memperoleh, mengahsilkan, dan menggunakn informasi dengan relevan dan berkualitas baik dari sumber internal maupun eksternal. Hal itu juga dapat membantu demi berlangsung kegiatan/program yang akan dilakukan. Selanjutnya, ketika kegiatan/program yang sedang berlangsung harus dilakukan pemantauan. Pematauan ini bermalsud untuk memperluas persepsi pemahaman dari kalangan pemerintah setempat maupun masyrakat Desa Kembes Satu. Kegiatan pemantauan ini mencakup evaluasi berkelanjutan, evaluasi terpisah, atau kombinasi dari keduanya untuk pemantauan yang lebih untuk memastikan pengendalian intern dalam penetapan APBDes di Desa Kembes Satu berfungsi sebagaimana mestinya.

\subsection{Analisis Kepatuhan APBDes}

Dalam Permendagri No. 113 Tahun 2014 dalam pasal 21 ayat (1) mengatakan rancangan peraturan desa tentang APBDes yang telah disepakati bersama sebagaimna dimaksud dalam pasal 20 ayat (3) dismapaikan oleh kepala desa kepada bupati/walikota melalui camat atau sebutan lain paling lambat 3 (tiga) hari sejak disepakti untuk dievaluasi. (2) Bupati/Walikota menetapkan haisl evaluasi rancangan APBDes sebagaimana dimaksud pada ayat (1) paling lama 20 (dua puluh) hari kerja sejak diterimanaya Rancangan Peraturan Desa tentang APBDes. (3) dalam hal BUpati/Walikota tidak memberikan hasil evaluasi dalam batas waktu itu sebagaimana dimaksud pada ayat (2) Peraturan Desa tersebut berlaku dengan sendirinya. (4) Dalam Hal Bupati/Walikota menyatkan hasil evalusi rancangan Peraturan Desa tentang APBDes tidak sesuai dengan kepentingan umum dan peraturan perundangan-undangan yang lebih tinggi, Kepala desa melakukan penyempurnaan paling lam 7 (tujuh) hari kerja terhitung diterimanya hasil evaluasi.

\section{KESIMPULAN DAN SARAN \\ 5.1 Kesimpulan}

Pemberlakuan Undang-undang desa No. 6 Tahun 2014, membawa perubahan struktur pemerintahan di Desa Kembes Satu dimana pemerintahan desa diberikan kewenangan untuk mengatur dan menjalankan sendiri urusan rumah tangga desanya, termasuk dalam hal pengeloaan keuangan desa seperti yang tertulis dalam Permendagri No. 113 Tahun 2014. Pengelolaan keuangan desa dapat dilakukan dengan perencanaan APBDes. APBDes yang berbasis pada program-program dan kegiatan-kegiatan, rancangan APBDes yang berdasarkan pada partisipasi dari masyarakat terhadap prioritas kebutuhan masyarakat. Undang-Undang No 6 Tahun 2014 tentang Desa merupakan undang-undang yang baru. Pelaksanaan dari undang-undang tersebut dalam pelaksanaan pembangunan oleh Kepala Desa di Desa Kembes Satu sudah baik. Hal ini dapat dilihat dari pembangunan yang dilaksanakan serta peningkatan kesejahteraan masyarakat desa dan kualitas hidup. Dalam Permendagri No. 113 Tahun 2014 Kepala Desa merupakan orang yang memegang kekuasaan dalam pengelolaan keuangan desa sebagaimana dimaksud pada ayat (1), yang mempunyai kewenangan:

a. Menetapkan kebijakan tentang pelaksanaan APBDesa;

b. Menetapkan PTPKD;

c. Melakukan tindakan yang mengakibatkan pengeluaran atas beban APBDesa. 


\subsection{Saran}

1. Masih perlu dilakukan sosialisai oleh pemerintah daerah mengenai Undang-Undang No. 6 Tahun 2014 Tentang Desa dan Permendagri No. 113Tahun 2014 tentang Pengelolaan Keuangan Desa

2. Peranan Kepala Desa terhadap pemberdayaan pembangunan secara menyeluruh hendaknya dilakukan secara konsisten dan berkesinambungan dan perlu dilakukan pengawasan yang secara rutin terutama terhadap kegiatan Pemerintah desa yang menunjukkan adanya kegiatan pembangunan.

\section{DAFTAR PUSTAKA}

Asy’ari, Safari Iman. 1993. Sosiologi Kota dan Desa. Surabaya: Usaha Nasional.

Abdul Halim (2002:143) http://www.sarjanaku.com/2012/12/pengertian-akuntansi pemerintahan.html.15 April 2018. (10.25)

Arinta, Kustandi. 2015.PengertianStandarAkuntansiPemerintahan. Edisi Pertama. Salemba Empat. Jakarta.

BachtiarArif, dkk. (2002:3) http://www.sarjanaku.com/2012/12/pengertian akuntansi-pemerintahan.html. 15 April 2018. (10.30)

Baswir, R. (2000:7) Definisi Akuntansi Pemerintahan Yuliansyah dan Rusmianto. 2016. AkuntansiDesa. Bandar Lampung. Penerbit: Salemba Empat

BachtiarArif, Iskandar. (2002:7).Pengertian Akuntansi Pemerintahan, Tujuan, Karakteristik,Syarat,RuangLingkupTerlengkap.

http://www.spengetahuan.com/2017/10/pengertianakuntansi-pemerintahan-tujuankarakteristik-syarat-ruang-lingkup.html. by:Dedi Rainer. 26 Oktober 2017 (23:18).

Hoesada, Jan. 2014. "Desa". http://www.ksap.org/sap/desa/, 8 Maret 2015.(10.25)

Hamzah, Ardi. 2015. Tata Kelola Pemerintah Desa Menuju Desa Mandiri, Sejahtera dan Partisipatoris. Surabaya. Pustaka.

PeraturanPemerintahanNomor 71 Tahun 2010 tentang Standar Akuntansi Pemerintahan

Peraturan Menteri Dalam Negeri Republik Indonesia tentang Pedoman Pengelolaan Keuangan Desa. Permendagri No. 37 Tahun 2007 sebagaimana telah diubah dengan Permendari No. 113 Tahun 2014. Jakarta: Sekretariat Negara.

Peraturan Menteri Dalam Negeri Republik Indonesia tentang Pedoman Pembangunan Desa. Permendari No. 114 Tahun 2014. Jakarta: Sekretariat Negara.

Peraturan Pemerintah tentang Peraturan Pelaksanaan Undang-Undang No. 6 Tahun 2014 tentang Desa. PP No. 43 Tahun 2014. Jakarta: Sekretariat Negara. 